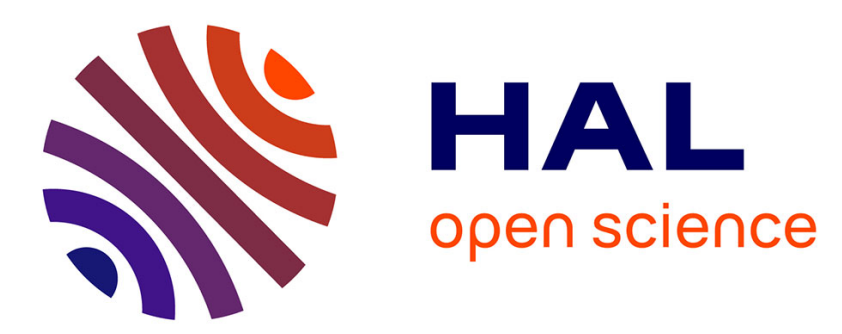

\title{
The use of n-alkanes for estimating feed intake in beef cows
}

\author{
M Oliván, K Osoro
}

\section{To cite this version:}

M Oliván, K Osoro. The use of n-alkanes for estimating feed intake in beef cows. Annales de zootechnie, 1995, 44 (Suppl1), pp.239-239. hal-00889398

\section{HAL Id: hal-00889398 \\ https://hal.science/hal-00889398}

Submitted on 1 Jan 1995

HAL is a multi-disciplinary open access archive for the deposit and dissemination of scientific research documents, whether they are published or not. The documents may come from teaching and research institutions in France or abroad, or from public or private research centers.
L'archive ouverte pluridisciplinaire HAL, est destinée au dépôt et à la diffusion de documents scientifiques de niveau recherche, publiés ou non, émanant des établissements d'enseignement et de recherche français ou étrangers, des laboratoires publics ou privés. 


\title{
The use of $\mathbf{n}$-alkanes for estimating feed intake in beef cows
}

\author{
M Oliván, K Osoro
}

Instituto de Experimentación y Promoción Agraria, Apdo 13, 33300 Villaviciosa, Asturias, Spain

$\mathrm{N}$-alkanes technique gives accurate estimation of herbage intake in sheep when using C33 and $\mathrm{C} 32$ as internal and external markers respectively, because their faecal recoveries are similar. Little information is available about the accuracy of the technique for estimating intake in cattle.

Ten dry cows ("Asturiana de Valles" breed) housed in metabolism cages were offered lucerne hay $(1.25 \mathrm{~kg} / 100 \mathrm{~kg}$ Live Weight) daily. This level of feeding was selected to ensure a complete consumption. From the day 7 and during 11 days the animals were dosed once daily at 10:00 $\mathrm{h}$ am with a paper pellet containing $879 \mathrm{mg}$ of $\mathrm{C} 32$. At the same time a faecal grab sample was collected from each animal. Average daily dry matter intake (kg $\mathrm{DM} /$ day) was estimated on the last three days from the C32 and $\mathrm{C} 33$ concentration found in diet and faeces as described by Mayes et al (1986, J Agric Sci Camb, 107, 161-170).

Diet, faeces and pellet samples were analysed according to the method of Mayes et al (1986) with some modifications. Faeces and diet samples were saponified by direct treatment with $1 \mathrm{M}$ ethanolic $\mathrm{KOH}$ at $90^{\circ} \mathrm{C}$ during 14 hours and alkanes extraction with heptane was performed at hot temperature (at $65^{\circ} \mathrm{C}$ ). Two internal standards (C22 and C34) were added to the samples at the beginning to estimate alkane concentration (Oliván et al, 1994, 45th Meeting of the EAAP, Edinburgh, 184). Samples were injected by on column injection on a $15 \mathrm{~m} \times 0.530 \mathrm{~mm}$ (I.D.) DB-1 megabore column (J\&W) in a Varian Model 3400 Gas Chromatograph. Gradients of temperature were used for the injector and the column.

Actual and estimated intake for each animal are shown in the Table. Intake was underestimated by the alkane method, the average bias being $-11 \%$. This bias is higher than that found in other experiments with beef cows feeding fresh perennial ryegrass (Mayes et al, 1986, Anim Prod, 42, 457) and dairy cows feeding conserved forages (hay and silage) and concentrates (Dillon and Stakelum, 1988, Proc VII Eur Grazing Workshop, Wageningen., The Netherlands ; Robaina et al, 1993, "The alkane workshop Harnessing Technology for the Beef Industry", University of New England, Armidale, 7).

In this experiment, intake level was low and probably the flow rate of nutrients through the digestive tract was quite slow. A long retention time of particles in the gut could cause a higher absorption of the natural alkane C33 (associated to the particulate phase of the digesta) than of the dosed alkane C32 (to some extent associated with the liquid phase, which passes more rapidly through the digestive tract). In this case the faecal recovery of the natural alkane $\mathrm{C} 33$ could be lower than that of the dosed alkane $\mathrm{C} 32$, being intake underestimated.

More information is needed about the possible effect of intake level on the alkane faecal recoveries and on the accuracy of the alkane method for estimating intake in cattle.

\begin{tabular}{ccccc}
\hline Cow & Weight $(\mathrm{kg})$ & Estimated intake $(\mathrm{g})$ & Actual intake $(\mathrm{g})$ & Discrepancy $(\%)$ \\
\hline 1 & 546 & 4965.49 & 5756.37 & -13.74 \\
2 & 454 & 4555.96 & 4783.93 & -2.63 \\
3 & 445 & 4199.75 & 5034.20 & -0.90 \\
4 & 472 & 3482.06 & 4545.25 & -16.57 \\
5 & 432 & 5890.91 & 3868.21 & -9.98 \\
6 & 362 & 4263.81 & 6157.97 & -4.34 \\
7 & 578 & 3481.03 & 5691.30 & -25.08 \\
8 & 530 & 3947.28 & 4475.60 & -22.22 \\
9 & 417 & 428 & 4561.58 & -13.47 \\
10 & 4 &
\end{tabular}

